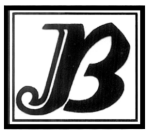

J. Bio-Sci. 29(2): 61-70, 2021 (December)

ISSN 1023-8654 http://www.banglajol.info/index.php/JBS/index DOI: https://doi.org/10.3329/jbs.v29i2.54955

\title{
EFFECTS OF PROBIOTIC AND ORGANIC MANURES FOR SOIL AMENDMENTS ON SEEDLING SURVIVABILITY AND LEAF CHLOROPHYLL FOR CROP IMPROVEMENT IN WHEAT (TRITICUM AESTIVUM L.)
}

\author{
MA Hossain ${ }^{1,2}$, MM Hasan ${ }^{3}$ and SMS Islam ${ }^{*}$ \\ ${ }^{1}$ Plant Biotechnology and Genetic Engineering Laboratory, Institute of Biological Sciences, University of \\ Rajshahi, Rajshahi-6205, Bangladesh \\ ${ }^{2}$ Directorate of Secondary and Higher Education, Dhaka-1000, Bangladesh \\ ${ }^{3}$ Agronomy and Agricultural Extension Department, University of Rajshahi, Rajshahi-6205, Bangladesh
}

\begin{abstract}
Under this study a total of nine treatments were considered for soil amendments where organic manures, chemical fertilizer and probiotics were used to evaluate the efficiency on growth and yield of wheat. On the basis of seedling disease incidence and chlorophyll presence parameters data were recorded on seedling infection at 14 days, seedling blight at 21 days, and chlorophyll content at 70 days after sowing. In this study the same experiments were conducted up to three years (2016-2019) and data were compiled and analyzed. It was observed that the disease prevalence attributes significantly decreased in $T_{5}$ (Trichoderma harzianum + vermicompost + green manuring) than other treatment combinations and control $\left(T_{0}\right)$. Noteworthy results were found on seedling health, application of probiotic and organic manures which significantly influenced the less infection of wheat. Besides this, chlorophyll content of wheat leaf and plant number with effective tiller enhanced largely under $\mathrm{T}_{8}$ (chemical fertilizer) than $\mathrm{T}_{4}$ (poultry manure + vermicompost + green manuring) and control ( $\left.\mathrm{T}_{0}\right)$. The main advantage of this research is to evaluate efficiency for growing healthy wheat plant which reflects on plant growth and yield and ultimately helps for food security.
\end{abstract}

Key words: Blight, Chlorophyll, Green and poultry manure, Infection, Vermicompost, Wheat

\section{Introduction}

Wheat (Triticum aestivum L.) is a staple food of billions of people all over the world and third most agricultural commodity next to rice and maize. The contribution of wheat is being increased significantly in different countries as Nigeria (1\% - 6.64\%), India $(11.85 \%-20.41 \%)$ and China $(12.20 \%-17.83 \%)$ regarding total $\mathrm{kcal}$ (Shewry and Hey 2015). In Bangladesh, wheat is one of the important grain crops regarding economic and consumption purposes. Wheat is used as industrial and commercial products for human consumption having high protein with others nutrients that is also a cheaper source of feed for livestock (Hammad et al. 2011). Land engaged for cultivation decreased with time to meet up the accommodation demand for geometric growth of population. To face the land limitation problem and provide food for increased population, sustainable use of land is burning issue for agricultural development (Haque and Islam 2018, Alam et al. 2020). The substantial pressure on land may create various constraints due to imbalanced and inadequate

*Author for correspondence: shahinul68@gmail.com 
application of fertilizer (Kumar and Abraham 2018). Chemical fertilizer may increase the wheat yield but prolonged application resulted human health hazard and imbalanced natural resources (Hossain et al. 2021a). So, need to link soil management and cropping design that are more environmentally sustainable (Karnel et al. 1994). Though transition period of three years produce lower performance but higher soil fertility found over time in conventional to organic farming (Tester 1990). So, for achieving higher yield and retain soil health sound organic amendments are felt to be important. A good soil should have organic matter content of more than 2.5\%. Most of the soils in Bangladesh have low to very low organic matter content, generally less than $1.5 \%$ (BARC 2012). Soil productivity is greatly influenced by the application organic manures like crop residues, green manure and animal manure in the soil-plant system (Yadvinder-Singh et al. 2008, Hossain et al. 2021a). Probiotics are live microorganisms which confer a beneficial health benefit on the host. Trichoderma is considered as a probiotic having the characteristic of fungi and considered as a potential and promising bio-control agent and growth promoter for many crops. Bio-fertilizer is regarded as an eco-friendly substitute of chemical fertilizer trends to enhance soil fertility and increase crop productivity and yield without creating harm to the environment (Hermosa et al. 2012, Hossain et al. 2021b). It was established that Trichoderma is a biological degrader and promotes plant disease defense, increasing the immunity of the plant. Hence, Trichoderma have tremendous opportunities for disease management of soil borne pathogens but also have the capacity to improve plant growth parameters and soil health. It is authentic that fairly good soil fertility and plant nutrients are important to farming. Hence to improve soil fertility and increase plant nutrients availability, efforts need to be made to increase soil organic matter content. So, in view of the above realities an initiative was undertaken to focus the probiotic and organic manure performance on wheat seedling and plant growth resulted on yield, which may help to increase the productivity of wheat.

\section{Materials and Methods}

\section{Soil and field preparation}

The present research work has been carried out in the Experimental Field of the Institute of Biological Sciences (IBSc) and laboratory works has been carried out at Plant Biotechnology and Genetic Engineering Lab., IBSc and Plant Pathology Lab., Department of Agronomy and Agricultural Extension, University of Rajshahi, Bangladesh during the period from July 2016 to June 2019. The experimental field geographically situated at $24^{\circ} 17^{\prime} \mathrm{N}$ latitude and $88^{\circ} 28^{\prime} \mathrm{E}$ longitude at an elevation of $20 \mathrm{~m}$ above the sea level belonging to the Agro-Ecological Zone-11 (AEZ-11). The soil of the experimental field has characteristics like poorly drained with moderately permeability, loam and slightly alkaline $(\mathrm{pH}=8.10)$ in nature. The physical properties of the experimental soil had moisture content $19.40 \%$, particle density $2.65 \mathrm{~g} / \mathrm{cc}$, bulk density 1.27 $\mathrm{g} / \mathrm{cc}$ and porosity $51.34 \%$. Furthermore, chemical properties like the organic matter content $1.20 \%, \mathrm{~K} 0.150$ cmol $(+) / k g$, total N 0.07\%, P $26.30 \mu \mathrm{g} / \mathrm{g}$, S $12.50 \mu \mathrm{g} / \mathrm{g}, \mathrm{Zn} 0.75 \mu \mathrm{g} / \mathrm{g}$, EC $145 \mu \mathrm{s} / \mathrm{cm}$ and C:N 10:1 were recorded.

\section{Experimental design and treatments}

The experiment was laid out in randomized complete block design (RCBD) with three replications. Three wheat varieties viz. BARI wheat-28 $\left(\mathrm{V}_{1}\right)$, BARI wheat-29 $\left(\mathrm{V}_{2}\right)$, BARI wheat-30 $\left(\mathrm{V}_{3}\right)$ and nine treatments $(T)$ including control $\left(T_{0}\right)$, rice straw + vermicompost + green manuring $\left(T_{1}\right)$, cow dung + vermicompost + green manuring $\left(T_{2}\right)$, compost + vermicompost + green manuring $\left(T_{3}\right)$, poultry manure + vermicompost + green 
manuring $\left(T_{4}\right)$, Trichoderma harzianum + vermicompost + green manuring $\left(T_{5}\right)$, mung bean residue + vermicompost + green manuring $\left(T_{6}\right)$, Trichoderma viride + vermicompost + green manuring $\left(T_{7}\right)$ and chemical fertilizer $\left(T_{8}\right)$ were used in this study. The unit plot was $5.0 \mathrm{~m}^{2}$ having a plot to plot $0.5 \mathrm{~m}$, bed to bed $0.25 \mathrm{~cm}$ distance and $1 \mathrm{~m}$ from surrounding the boundary. The total unit plot was 81 . Seeds of Dhaincha (Sesbania rostrata) were sown at the rate of $50 \mathrm{~kg} / \mathrm{ha}$ (BARI 2014) and after 50 days young succulent green manure plants incorporated into the soil to the respective plots (Dubey et al. 2015). Crop residues (rice straw and mung bean), cow dung, compost and poultry litter were applied at the rate 10 t/ha before 7 days of sowing. Vermicompost was applied 5 t/ha and Trichoderma spp. suspension $\left(1 \times 10^{6} \mathrm{cfu} / \mathrm{g}\right.$ at the rate $\left.5 \mathrm{~kg} / \mathrm{ha}\right)$ before sowing. In case of chemical treatment, one third urea (200 kg/ha), TSP $160 \mathrm{~kg} / \mathrm{ha}, \mathrm{MP} 45 \mathrm{~kg} / \mathrm{ha}$ and gypsum $115 \mathrm{~kg} / \mathrm{ha}$ was used as basal dose (BARI 2014). Rest of the urea was applied following two installments, one at 21 days after sowing (DAS) and rest one at 55 DAS.

\section{Data collection on seedling health, leaf chlorophyll content and plant characters}

\section{Seedling infection}

The seedlings which were found yellow and rotted at the base are considered as infected. From germination up to 14 days regular observation was made and infected seedlings were counted in each plot. Infection was estimated by the following formula:

$$
\% \text { Seedling infection }=\frac{\text { Number of infected seedlings }}{\text { Total number of seedlings }} \times 100
$$

\section{Seedling blight}

Seedlings which were dead and became straw in color defined as seedling blight. Seedling infection is treated as the first step of seedling blight. Thus, blighted seedlings were counted at 21 DAS in every plot. It was estimated as by the following formula:

$$
\% \text { Seedling blight }=\frac{\text { Number of blighted seedlings }}{\text { Total number of seedlings }} \times 100
$$

\section{Leaf chlorophyll content}

The atLEAF handled chlorophyll meter was used to assess leaf greenness. The meter determines light transmittance through the leaf at 660 and $940 \mathrm{~nm}$ wavelengths. The readings were obtained by inserting the middle portion of the topmost fully expanded leaf in the slit of the meter. At least three readings from leaves of randomly selected plants in each plot were recorded and mean value was determined. Abnormally looking or insect attacked plants were not selected for measurement (Ali et al. 2020).

\section{Total plant $/ \mathrm{m}^{2}$}

Before harvesting $1 \mathrm{~m}^{2}$ area was selected with quadrate and the number of total plants was counted. This operation was done in each plot preferably choosing the five rows in the middle of the plot. 


\section{Effective tiller/plant}

The numbers of tillers bearing panicles were counted at harvest with the help of quadrate from $1 \mathrm{~m} \times 1 \mathrm{~m}$ area, which expressed as effective tillers/plant.

\section{Statistical analysis}

The recorded data were compiled and tabulated for statistical analysis. The data were analyzed statistically for analysis of variance (ANOVA) and Duncan's Multiple Range Test (DMRT) through r-studio by the "Agricolae" package.

\section{Results}

\section{Seedling infection}

Regarding various treatments effect, the lower rate of seedling infection $(0.32 \%)$ was found after application Trichoderma harzianum $\left(T_{5}\right)$ in comparison with the maximum infection from $T_{0}(2.32 \%)$ in 2018-2019. All the treatments in the experimental period presented significant differences among each other. But $T_{1}$ (rice straw + vermicompost + green manuring) and $T_{8}$ (chemical fertilizer) was statistically identical. Reduction of seedling infection at 14 DAS under different soil amendments showed more or less the following order as $T_{5}>T_{7}>T_{4}>T_{3}>T_{2}>T_{6}>T_{1}>T_{8}>T_{0}$ during the whole research period shown in Table 1.

\section{Seedling blight}

Under this study, recorded results showed that there was a significant variation among the treatments. The highest inhibition effect against seedling blight $(0.87 \%)$ was observed by treatment $T_{5}$ and the lowest (4.74\%) from control ( $\left.T_{0}\right)$ during 2018-2019 (Fig.1 a-b). Next to treatment $T_{5}$, the treatment $T_{7}$ also showed remarkable effect in reducing seedling blight (1.07\%) which was statistically identical (1.09\%) with $\mathrm{T}_{4}$ (Table 1).
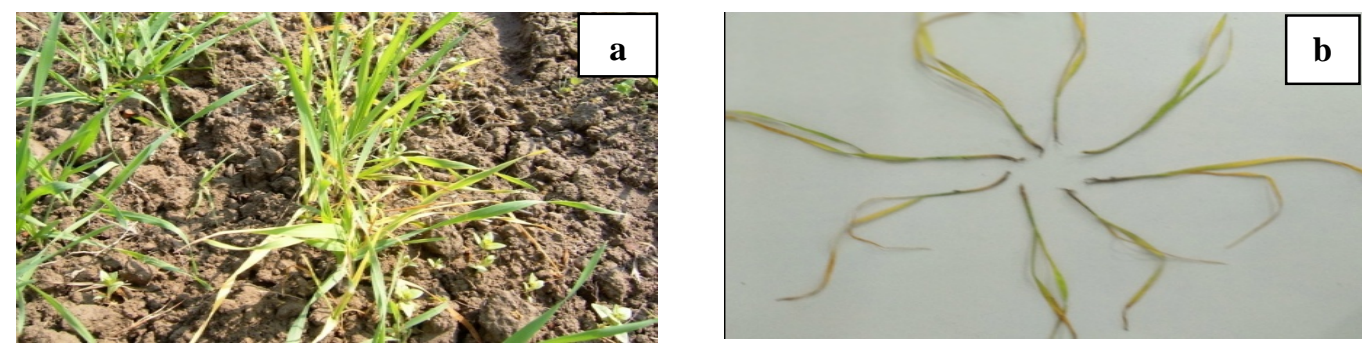

Fig. 1(a-b): Seedling status and plant growth by adding probiotic and organic manures for soil amendments, a) seedling infection and, b) seedling blight.

\section{Leaf chlorophyll content}

A significant difference was observed from various soil amendments for the chlorophyll content of wheat leaf at 70 DAS. The highest value of chlorophyll content (51.48 SPAD) was recorded from chemical fertilizer $\left(T_{8}\right)$ and which was followed by $T_{4}$ (48.37 SPAD) and $T_{5}$ (48.08). In this regard, the smallest value (40.33 SPAD) was noticed from To during the season 2018-2019. Due to soil amendment with chemical fertilizer $\left(T_{8}\right)$ 
provided more chlorophyll content and the trend was maintained from beginning to the end of the study (Table 1).

Table 1. Effect of organic and probiotic soil amendments on seedling infection and seedling blight of wheat

\begin{tabular}{|c|c|c|c|c|c|c|c|c|c|}
\hline \multirow{3}{*}{ Treat. } & \multicolumn{3}{|c|}{ Seedling infection (\%) } & \multicolumn{3}{|c|}{ Seedling blight (\%) } & \multicolumn{3}{|c|}{ Leaf chlorophyll content (SPAD) } \\
\hline & \multicolumn{3}{|c|}{14 DAS } & \multicolumn{3}{|c|}{21 DAS } & \multicolumn{3}{|c|}{$70 \mathrm{DAS}$} \\
\hline & $\begin{array}{l}2016- \\
2017\end{array}$ & $\begin{array}{l}2017- \\
2018\end{array}$ & $\begin{array}{l}2018- \\
2019\end{array}$ & $\begin{array}{l}2016- \\
2017\end{array}$ & $\begin{array}{l}2017- \\
2018\end{array}$ & $\begin{array}{l}2018- \\
2019\end{array}$ & $\begin{array}{l}2016- \\
2017\end{array}$ & $\begin{array}{l}2017- \\
2018\end{array}$ & $\begin{array}{c}2018 \text { - } \\
2019\end{array}$ \\
\hline$T_{0}$ & $\begin{array}{c}2.14 \\
\pm 0.12 \mathrm{a}\end{array}$ & $\begin{array}{c}1.99 \\
\pm 0.09 a\end{array}$ & $\begin{array}{r}2.32 \\
\pm 0.13 a\end{array}$ & $\begin{array}{c}3.52 \\
\pm 0.16 a\end{array}$ & $\begin{array}{c}3.30 \\
\pm 0.16 a\end{array}$ & $\begin{array}{c}4.74 \\
\pm 0.20 \mathrm{a}\end{array}$ & $\begin{array}{c}38.26 \\
\pm 0.85 h\end{array}$ & $\begin{array}{c}38.82 \\
\pm 0.90 \mathrm{~g}\end{array}$ & $\begin{array}{c}40.33 \\
\pm 0.79 d\end{array}$ \\
\hline $\mathrm{T}_{1}$ & $\begin{array}{c}1.49 \\
\pm 0.03 b\end{array}$ & $\begin{array}{c}1.47 \\
\pm 0.05 b\end{array}$ & $\begin{array}{c}1.46 \\
\pm 0.09 \mathrm{~b}\end{array}$ & $\begin{array}{c}2.53 \\
\pm 0.08 \mathrm{~b}\end{array}$ & $\begin{array}{c}2.41 \\
\pm 0.08 b\end{array}$ & $\begin{array}{r}2.48 \\
\pm 0.19 c\end{array}$ & $\begin{array}{c}40.18 \\
\pm 0.90 \mathrm{~g}\end{array}$ & $\begin{array}{c}41.62 \\
\pm 0.86 f\end{array}$ & $\begin{array}{c}42.77 \\
\pm 0.87 \mathrm{c}\end{array}$ \\
\hline $\mathrm{T}_{2}$ & $\begin{array}{c}1.34 \\
\pm 0.04 d\end{array}$ & $\begin{array}{c}1.24 \\
\pm 0.05 c\end{array}$ & $\begin{array}{c}1.20 \\
\pm 0.04 \mathrm{c}\end{array}$ & $\begin{array}{c}2.17 \\
\pm 0.06 c\end{array}$ & $\begin{array}{c}2.04 \\
\pm 0.04 d\end{array}$ & $\begin{array}{c}2.11 \\
\pm 0.08 d\end{array}$ & $\begin{array}{c}41.39 \\
\pm 0.87 f\end{array}$ & $\begin{array}{c}43.56 \\
\pm 1.05 \mathrm{de}\end{array}$ & $\begin{array}{c}42.96 \\
\pm 0.76 c\end{array}$ \\
\hline$T_{3}$ & $\begin{array}{c}0.93 \\
\pm 0.04 \mathrm{e}\end{array}$ & $\begin{array}{c}0.87 \\
\pm 0.03 d\end{array}$ & $\begin{array}{c}0.92 \\
\pm 0.05 d\end{array}$ & $\begin{array}{c}1.77 \\
\pm 0.05 d\end{array}$ & $\begin{array}{c}1.71 \\
\pm 0.05 e\end{array}$ & $\begin{array}{c}1.61 \\
\pm 0.04 \mathrm{e}\end{array}$ & $\begin{array}{c}42.45 \\
\pm 0.85 d\end{array}$ & $\begin{array}{c}43.85 \\
\pm 1.04 \mathrm{~d}\end{array}$ & $\begin{array}{r}44.09 \\
\pm 0.85 c\end{array}$ \\
\hline $\mathrm{T}_{4}$ & $\begin{array}{c}0.59 \\
\pm 0.02 f\end{array}$ & $\begin{array}{c}0.58 \\
\pm 0.02 \mathrm{e}\end{array}$ & $\begin{array}{c}0.55 \\
\pm 0.01 \mathrm{e}\end{array}$ & $\begin{array}{c}1.24 \\
\pm 0.05 \mathrm{e}\end{array}$ & $\begin{array}{c}1.19 \\
\pm 0.06 f\end{array}$ & $\begin{array}{c}1.09 \\
\pm 0.05 f\end{array}$ & $\begin{array}{r}44.59 \\
\pm 0.81 b\end{array}$ & $\begin{array}{c}46.63 \\
\pm 0.89 b\end{array}$ & $\begin{array}{c}48.37 \\
\pm 0.80 \mathrm{~b}\end{array}$ \\
\hline$T_{5}$ & $\begin{array}{c}0.35 \\
\pm 0.02 \mathrm{~g}\end{array}$ & $\begin{array}{c}0.34 \\
\pm 0.02 \mathrm{~g}\end{array}$ & $\begin{array}{c}0.32 \\
\pm 0.02 g\end{array}$ & $\begin{array}{c}0.93 \\
\pm 0.06 f\end{array}$ & $\begin{array}{c}0.87 \\
\pm 0.04 \mathrm{~g}\end{array}$ & $\begin{aligned} & 0.87 \\
\pm & 0.05 g\end{aligned}$ & $\begin{array}{r}43.03 \\
\pm 0.85 c\end{array}$ & $\begin{array}{c}44.73 \\
\pm 0.91 \mathrm{c}\end{array}$ & $\begin{array}{c}48.08 \\
\pm 0.61 b\end{array}$ \\
\hline $\mathrm{T}_{6}$ & $\begin{array}{c}1.43 \\
\pm 0.02 \mathrm{c}\end{array}$ & $\begin{array}{c}1.44 \\
\pm 0.06 \mathrm{~b}\end{array}$ & $\begin{array}{c}1.42 \\
\pm 0.08 b\end{array}$ & $\begin{array}{c}2.44 \\
\pm 0.07 \mathrm{~b}\end{array}$ & $\begin{aligned} & 2.33 \\
\pm & 0.08 \mathrm{bc}\end{aligned}$ & $\begin{array}{c}2.16 \\
\pm 0.11 d\end{array}$ & $\begin{array}{c}41.08 \\
\pm 0.89 f\end{array}$ & $\begin{array}{c}41.80 \\
\pm 0.92 f\end{array}$ & $\begin{array}{c}43.06 \\
\pm 0.63 c\end{array}$ \\
\hline $\mathrm{T}_{7}$ & $\begin{array}{c}0.57 \\
\pm 0.02 f\end{array}$ & $\begin{array}{c}0.46 \\
\pm 0.02 f\end{array}$ & $\begin{array}{c}0.45 \\
\pm 0.03 f\end{array}$ & $\begin{array}{c}1.29 \\
\pm 0.04 \mathrm{e}\end{array}$ & $\begin{array}{c}1.11 \\
\pm 0.03 f\end{array}$ & $\begin{array}{c}1.07 \\
\pm 0.06 f\end{array}$ & $\begin{array}{c}41.78 \\
\pm 0.92 \mathrm{e}\end{array}$ & $\begin{array}{c}43.45 \\
\pm 0.95 \mathrm{e}\end{array}$ & $\begin{array}{c}45.11 \\
\pm 0.71 \mathrm{c}\end{array}$ \\
\hline $\mathrm{T}_{8}$ & $\begin{array}{c}1.48 \\
\pm 0.10 c\end{array}$ & $\begin{array}{c}1.47 \\
\pm 0.08 \mathrm{~b}\end{array}$ & $\begin{array}{c}1.42 \\
\pm 0.04 b\end{array}$ & $\begin{aligned} & 2.44 \\
\pm & 0.09 \mathrm{~b}\end{aligned}$ & $\begin{array}{c}2.26 \\
\pm 0.04 \mathrm{c}\end{array}$ & $\begin{aligned} & 2.57 \\
\pm & 0.11 b\end{aligned}$ & $\begin{array}{c}47.14 \\
\pm 0.97 a\end{array}$ & $\begin{array}{r}48.92 \\
\pm 1.08 \mathrm{a}\end{array}$ & $\begin{array}{c}51.48 \\
\pm 0.70 \mathrm{a}\end{array}$ \\
\hline LS & ** & ** & ** & ** & ** & ** & ** & ** & ** \\
\hline $\begin{array}{l}\mathrm{CV} \\
(\%)\end{array}$ & 5.42 & 6.89 & 4.38 & 5.59 & 6.16 & 4.30 & 0.80 & 0.79 & 5.09 \\
\hline
\end{tabular}

Each value represents the average of three replicates. In the column, mean values bearing similar letter(s) or without letter are identical and those having dissimilar letters are differed significantly as per Duncan's Multiple Range Test. $T_{0}=$ control, $T_{1}=$ rice straw + vermicompost + green manuring, $T_{2}=$ cow dung + vermicompost + green manuring, $T_{3}=$ compost + vermicompost + green manuring, $T_{4}=$ poultry manure + vermicompost + green manuring, $T_{5}=T$. harzianum + vermicompost + green manuring, $T_{6}=$ mung bean residues + vermicompost + green manuring, $T_{7}=T$. viride + vermicompost + green manuring, $T_{8}=$ chemical fertilizer, $\mathrm{SPAD}=$ The soil plant analysis development. $\mathrm{LS}=$ level of significance, ${ }^{\star *}=1 \%$ level of significance, $\mathrm{CV}=$ co-efficient of variation. 


\section{Total plant $/ \mathrm{m}^{2}$}

Total plant/ $\mathrm{m}^{2}$ at harvest varied significantly due to different soil amendments all over the study period. The highest frequency of total plant/ $/ \mathrm{m}^{2}$ was found in $\mathrm{T}_{8}(199.11 \%)$ and the lowest result was recorded in $\mathrm{T}_{0}$ (158.67\%) in 2016-2017 (Fig. 2). The next highest value was recorded from $T_{4}$ (191.56\%) and $T_{5}(185.00 \%)$ had the statistical likeness. In the year 2017-2018, total plant $/ \mathrm{m}^{2}$ exhibited the matching trend due to various soil amendments as reported in 2016-2017. Where the highest (207.78\%) plant/ $\mathrm{m}^{2}$ produced by $\mathrm{T}_{8}$ and had similar identity with the second most from $\mathrm{T}_{4}(202.89 \%)$. The lowest total plant $/ \mathrm{m}^{2}(163.89 \%)$ was noticed in $\mathrm{T}_{0}$ coupled with $\mathrm{T}_{1}(170.22 \%)$. Among the different soil amendments $\mathrm{T}_{8}(216.11 \%)$ performed superior results besides $\mathrm{T}_{4}(209.89 \%)$ to other treatments in 2018-2019. Rest of the treatments were showed also significant difference ranked as descending by $\mathrm{T}_{5}(199.78 \%), \mathrm{T}_{7}(190.22 \%), \mathrm{T}_{3}(187.22 \%), \mathrm{T}_{2}(179.00 \%), \mathrm{T}_{6}(177.67 \%)$ and $T_{1}(173.44 \%)$, whereas the lowest one in $T_{0}(159.00 \%)$.

\section{Effective tiller/plant}

Under this study, recorded results on effective tiller/plant showed significant difference by the influence of treatments. Out of different soil amendments, chemical fertilizer $\left(T_{8}\right)$ and poultry manure $\left(T_{4}\right)$ performed as superior to the rest of the treatments mainly unamend ( $\left.T_{0}\right)$ all over the research period (Fig. 3). On the basis of the above statement, $T_{8}$ was produced the maximum number of effective tiller/plant (3.49\%) followed by $\mathrm{T}_{4}$ (3.40\%), whereas the minimum value (2.07\%) was given by $\mathrm{T}_{0}$ in 2016-2017. During 2017-2018, treatments were exhibited approximately equal performance with slight increase of effective tiller/plant. However, $3.64 \%$ and $2.10 \%$ were the greater and less value of effective tiller/plant obtained by treatment $\mathrm{T}_{8}$ and $\mathrm{T}_{0}$. In the last year 2018-2019, the maximum value on this parameter was found from $\mathrm{T}_{8}(3.89 \%)$ and $\mathrm{T}_{4}(3.69 \%)$ and then gone downward as followed $\mathrm{T}_{5}(3.36 \%)>\mathrm{T}_{7}(3.22)>\mathrm{T}_{3}(3.09)>\mathrm{T}_{2}(2.91 \%)>\mathrm{T}_{6}(2.84 \%)$ $>\mathrm{T}_{1}(2.73 \%)$ over $\mathrm{T}_{0}(2.16 \%)$.

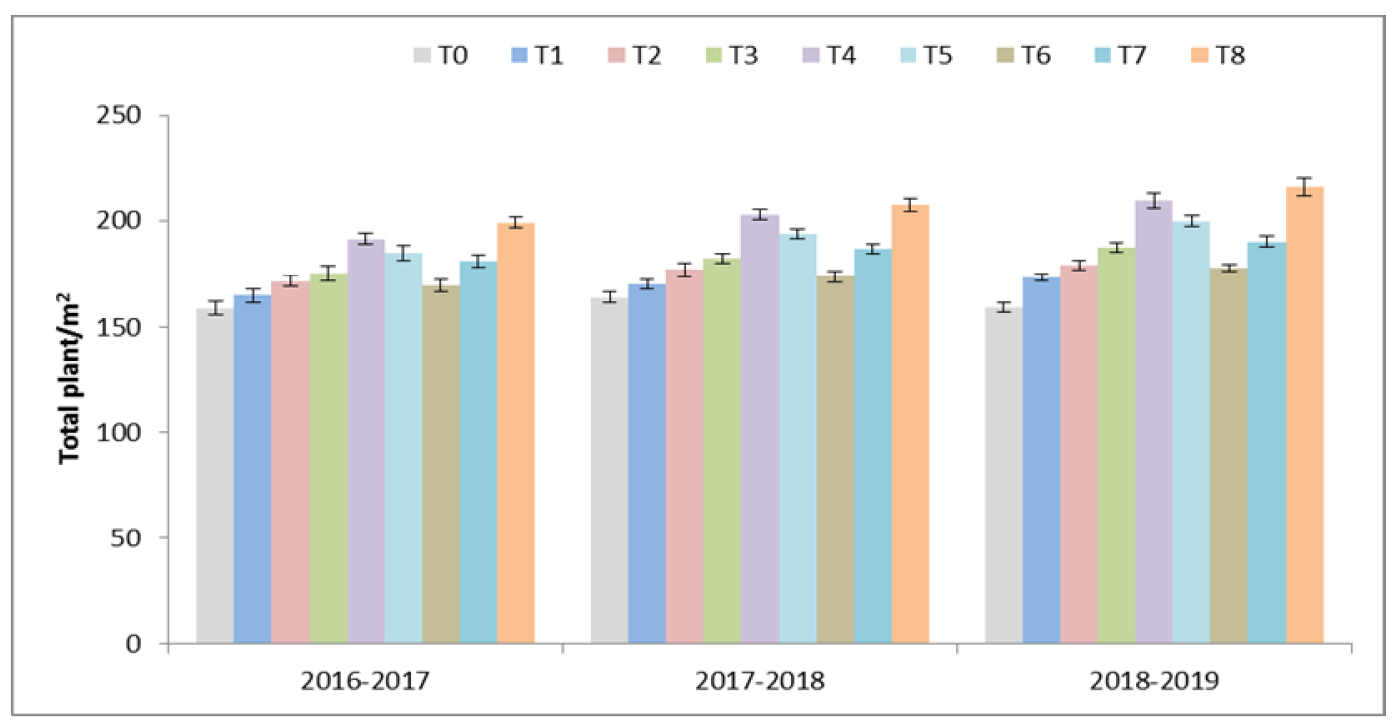

Fig. 2: Effect of organic and probiotic soil amendments on total plant $/ \mathrm{m}^{2}$ of wheat. 


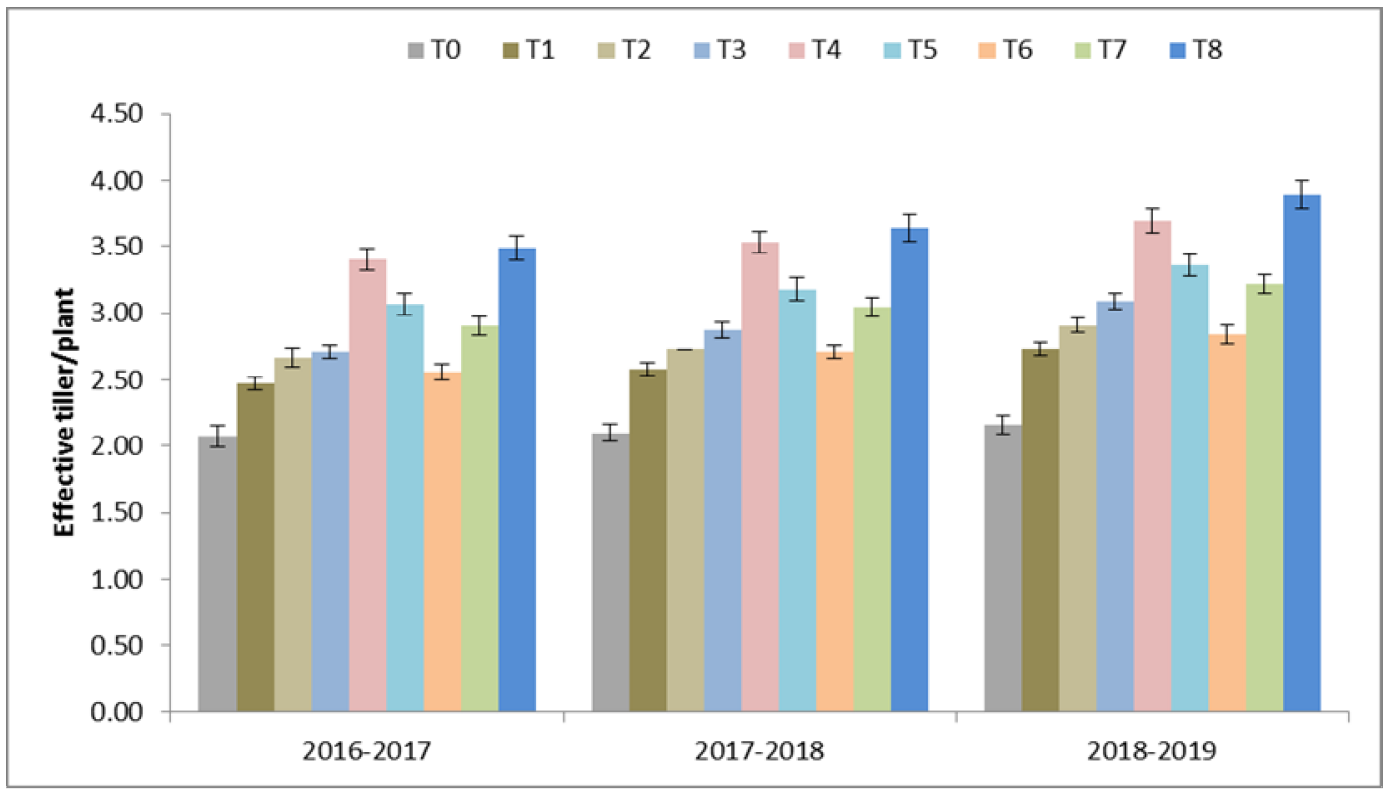

Fig. 3: Effect of organic and probiotic soil amendments on effective tiller/plant of wheat.

\section{Discussion}

\section{Seedling infection}

A significant variation of seedling infection was noticed all over the research period. The trend of infection was found to decline with the progress of the study due to application of probiotic and organic manure. The highest rate of seedling infection was found in $T_{0}(2.32 \%)$, while the minimum rate of infection was recorded from $T_{5}(0.32 \%)$ in 2018-2019. It might be due to the definite role of probiotic fortified-organic manures that exerted antagonistic effect against the fungi causing seedling infection. Furthermore, the addition of organic matter may create a hospitable environment for growth and development of fungal antagonists resulting in enhanced biocontrol activity (Sarkar et al. 2002). This finding was in harmony with the reports Tewari and Rajbir (2005).

\section{Seedling blight}

Seedling infection later on converted into seedling blight. Like seedling infection, this parameter was also varied significantly under various treatments all over the study period. The control activity against seedling blight was highly observed by $T_{5}(0.87 \%)$ and the lowest exhibited from check $T_{0}(4.74 \%)$ during 2018-2019. Such result may be obtained for the efficacy of the prohibitory and biocontrol action of the treatment. This efficacy of Trichoderma fortified-organic manures was evaluated to reduce the pre-emergence and post-emergence seedling mortality, diseases of stem and root of chickpea by Talukder et al. (2017). Similar control activity of Trichoderma spp. against plant pathogen and seedling mortality was also reported by Bhuiyan et al. (2007) and Ha 2010. 


\section{Leaf chlorophyll content}

Chlorophyll content of leaf from diverse treatments was provided significant dissimilarities from beginning to end of the study. On the focus of organic amendments, treatment $T_{4}$ (48.37 SPAD) next to $T_{8}$ (51.48 SPAD) had the bigger accumulation of chlorophyll and the smaller was noticed from To (40.33 SPAD). It may probably relate with the decomposition rate of organic manures that happened in case of $T_{4}$ treatment. This result was supported by Khan et al. (2005) with the statement that $\mathrm{N}$ supply in organic treatment is generally restricted and slows $\mathrm{N}$ mineralization as compared to crop demand of $\mathrm{N}$. Chlorophyll content is closely related to the presence of $\mathrm{N}$ and poultry manure $\left(\mathrm{T}_{4}\right)$ had the higher ability of supplying $\mathrm{N}$. This result is an agreement with the findings of Sims and Wolf (1992), Khanam et al. (2001), Ru et al. (2012) and Krishna (2013).

\section{Total plant $/ \mathrm{m}^{2}$}

The parameter plant $/ \mathrm{m}^{2}$ is one of the major vegetative growth indicators of wheat. The best values of plant $/ \mathrm{m}^{2}$ were obtained from $\mathrm{T}_{8}(216.11 \%)$ and then $\mathrm{T}_{4}(202.81 \%)$ where the lowest at $\mathrm{T}_{0}(158.66 \%)$. The ability of such enhancement plant $/ \mathrm{m}^{2}$ due to application of poultry manure might contain high amounts of nutrients and organic matter that improved the soil structure and environment which aids density of plant. Result in the study was in the same manner previously notified by Hassan (2002), Dauda et al. (2008) and Ismaeil et al. (2012).

\section{Effective tiller/plant}

Tillering is one of the important growth stages of wheat which provides the necessary stalks for satisfactory production. Though tillers are lateral branches which emerge from the main stem, but not all produce an ear. Generally, the first two-three tillers are noted as productive tillers of wheat and production is related to environment and nutrition supply. In this investigation, a greater number of productive tiller/plant was demonstrated by $T_{8}(3.89 \%)$ and $T_{4}(3.69 \%)$. This advancement of effective tiller might be due to optimum moisture and available nutrients provided by poultry manure which may have created the favorable condition for wheat growth. This was supported by Simpson (1990), Eck and Stewart (1995), Mitchell and Tu (2005) and Sistani et al. (2008). The result of this investigation was related to the observations of Belefant-Miller (2007), Abbasi and Khaliq (2016).

\section{Conclusion}

Quick response of chemical fertilizer offered an instant results nevertheless it has harmful effect not only crops as well as soil health. Therefore, organic soil amendment has given emphasis in this study. Seedling survivability was found greater by the application of probitic combination, whereas potential and sustainable improvement of wheat growth with organic soil amendment was found. Regarding this findings, Trichoderma harzianum, green manure and vermicompost may be useful for against seedling mortality and in addition of green manure, vermicompost and poultry manure may be a worthy substitute for wheat growth. Data of this study revealed that the probiotic particularly Trichoderma harzianum produce healthier seedling and poultry manure exhibited the capacity of supply nutrient demand and chlorophyll synthesis for improvement in growth of wheat as compared to other manures. 


\section{References}

Abbasi MK and Khaliq A (2016). Nitrogen mineralization of a loam soil supplemented with organic-inorganic amendments under laboratory incubation. Frontiers in Plant Science, 7: 1-9.

Alam MS, Haydar FMA and Hoque A (2020). Effects of planting method on yield and yield attributing characters in chickpea (Cicer arietinum L.). Journal of Bio-Science, 28(20): 105-110.

Ali AM, Ibrahim SM and Bijay-Singh (2020). Wheat grain yield and nitrogen uptake prediction using atLeaf and GreenSeeker portable optical sensors at jointing growth stage. Information Processing in Agriculture, 7(3): 375-383.

BARC (2012). Fertilizer Recommendation Guide. Farmgate, Dhaka-1215, Bangladesh.

BARI (2014). Krishi Projukti Hatboi (Handbook on Agro-Technology), 6th Edition, Gazipur-1701, Bangladesh.

Belefant-Miller H (2007). Poultry litter induces tillering in rice. Journal of Sustainable Agriculture, 31(1): 151-160.

Bhuiyan MK, Ahmed I and Begum F (2007). Integrated management of seedling mortality of cauliflower (Brassica oleraceae var. capitata) caused by Sclerotium rolfsii. Journal of Agriculture, Science and Technology, 8(1\&2): 79-86.

Dauda SN, Ajayi FA and Ndor E (2008). Growth and yield of water melon (Citrullus lanatus) as affected by poultry manure application. Journal of Agriculture and Social Science, 4(3): 121-124.

Dubey L, Dubey M and Jain P (2015). Role of green manure in organic farming. Plant archives, 15(1): 23-26.

Eck HV and Stewart BA (1995). Manure in soil amendments and environmental quality. Lewis publication, Boca Raton, Florida: 169-98.

Ha TN (2010). Using Trichoderma species for biological control of plant pathogens in Viet Nam. International Society for Southeast Asian Agricultural Sciences, 16(1): 17-21.

Hammad HM, Khaliq A, Ashfaq A, Aslam M, Malik AH, Farhad W and Laghari KQ (2011). Influence of different organic manures on wheat productivity. International Journal of Agriculture and Biology, 13(1): 137-140.

Haque M and Islam SMS (2018). Effect of sowing time on yield and yield contributing characters in comparison with local and European genotypes of barley (Hordeum Vulgare L.). SKUAST Journal of Research, 20(1): 27-31.

Hassan EA (2002). Effect of chicken manure and season on the performance and HCN Content of two forage sorghum cultivar. PhD Thesis, Faculty of Agriculture, University of Khartoum, Sudan.

Hermosa R, Viterbo A, Chet I and Monte E (2012). Plant-beneficial effects of Trichoderma and of its genes. Microbiology, 158: $17-25$.

Hossain MA, Hasan MM and Islam SMS (2021b) Sustainability of wheat (Triticum aestivum L.) yield and improvement of seed quality through probiotic and organic soil amendment. Bangladesh Agronomy Journal 389. Bangladesh Agronomy Journal, 24(1).

Hossain MA, Hasan MM, Hossain MB and Islam SMS (2021a). Effects of probiotic and organic fertilizers as soil amendments on growth and yield of wheat plants. Applied Biological Research, 23(2): 157-164. DOI: 10.5958/09744517.2021.00021.5

Ismaeil FM, Abusuwar AO and El Naim AM (2012). Influence of chicken manure on growth and yield of forage sorghum (Sorghum bicolor L. Moench). International Journal of Agriculture and Forestry, 2(2): 56-60.

Karlen DL, Varvel GE, Bullock DG and Cruse RM (1994). Crop rotations for the 21st Century. Advances in Agronomy, 53: 01-45.

Khan MA, Shukla AK, Upadhyay NC and Singh OP (2005). Nutrient management strategies for maize-potato-wheat cropping system in typic ustochrept soils. Potato Journal, 32: 167-168. 
Khanam M, Rahman MH and Islam MR (2001). Effect of manure and fertilizers on the growth and yield of BRRI Dhan 30. Pakistan Journal of Biological Sciences, 4: 172-174.

Krishna KR (2013). Agroecosystems: soils, climate, crops nutrients dynamics and productivity. Apple Academic Press Incorporated, Toronto, Canada: 1-517.

Kumar S and Abraham T (2018). Productivity potential of wheat under certified organic production system. International Journal of Current Microbiology and Applied Sciences, 7(10): 281-288.

Mitchell CC and Tu S (2005). Long-term evaluation of poultry litter as a source of nitrogen for cotton and corn. Agronomy Journal, 97: 399-407.

Ru SH, Zhang GY, Niu JF, Sun SY, Wang L and Geng N (2012). Effects of chicken manure application on crop yields and soil nutrients accumulation in wheat-corn rotation system. International Conference on Biomedical Engineering and Biotechnology, 28 May 2012, pp. 1392-1396.

Sarkar MK, Acharya A and Sengupta PK (2002). Management of sheath blight of rice caused by Rhizoctonia solani by oilcake amendment of soil. Journal of Mycopathological Research, 40(2): 153-158.

Shewry PR and Hey SJ (2015). The contribution of wheat to human diet and health. Food and Energy Security, 4(3): 178-202.

Simpson TW (1990). Agronomic use of poultry industry waste. Poultry Science, 70: 1126-1131.

Sims TJ and Wolf DC (1992). Poultry waste management: Agricultural and environmental issues. Advanced Agronomy, 52: $1-84$.

Sistani KR, Sikora FJ and Rasnake M (2008). Poultry litter and tillage influences on corn production and soil nutrients in a Kentucky silt loam soil. Soil and Tillage Research, 98(2): 130-139.

Talukdar P, Siddiqa MM, Masum MMI, Habibullah ABM and Bhuiyan AKM (2017). Effect of Trichoderma fortified compost on disease suppression, growth and yield of chickpea. International Journal of Environment, Agriculture and Biotechnology, 2(2): 831-839.

Tester CF (1990). Organic amendment effects on physical and chemical properties of a sandy soil. Soil Science Society of America Journal, 54(3): 827-831.

Tewari L and Rajbir S (2005). Biological control of sheath blight of rice by Trichoderma harzianum. Indian Phytopathology, 58: 35-40.

Yadvinder-Singh, Bijay-Singh, Gupta RK, Ladha JK, Bains JS and Singh J (2008). Evaluation of press mud cake as a source of nitrogen and phosphorus for the rice-wheat cropping system in the Indo-Gangetic plains of India. Biology and Fertility of Soils, 45: 289-296.

(Manuscript received on 21 February 2021; revised on 02 June 2021) 